\title{
Role of IL-10 in Hepatocyte Tight Junction Alteration in Mouse Model of Experimental Colitis
}

\author{
Emanuela Mazzon, ${ }^{1}$ Domenico Puzzolo, ${ }^{1}$ Achille P. Caputi, ${ }^{2}$ and Salvatore Cuzzocrea ${ }^{2}$ \\ ${ }^{1}$ Department of Biomorphology, School of Medicine \\ ${ }^{2}$ Institute of Pharmacology, University of Messina, Messina, Italy \\ Accepted June 4, 2002
}

\begin{abstract}
Background: A variety of hepatobiliary abnormalities have been described in patients with chronic inflammatory bowel diseases (IBDs). The purpose of this study was to investigate the role of endogenous IL-10 in alteration of hepatocyte TJ paracellular barrier and in the rapid transcytotic vesicular pathway modification associated with intestinal inflammation.

Materials and methods: To address this question, we used an experimental model of colitis, induced by dinitrobenzene sulfonic acid (DNBS). When compared to DNBS-treated IL-10 wild-type (IL-10WT) mice, DNBStreated IL-10 knock-out mice (IL-10KO) mice experienced a higher rate of the extent and severity of the histological signs of colon injury.

Results: Colon and liver levels of the pro-inflammatory cytokines tumour necrosis factor, interleukin- $1 \beta$ and interleukin-6 were also greatly enhanced in IL-10KO mice in comparison to wild-type mice. Liver histology from IL-10KO and IL-10WT did not show any parenchymal and portal tract inflammation at 4 days after DNBS
\end{abstract}

administration. Serum total bilirubin and Alanine aminotransferase, were significantly increased in DNBS-IL$10 \mathrm{KO}$ mice vs. DNBS-IL-10KO mice.

Therefore, we found an increase of tight junctional permeability to lanthanum nitrate (molecular weight, 433) in the livers from DNBS-treated IL-10WT mice; lanthanum accumulated throughout the junctional area up to the most apical region bordering the lumen. Absence of a functional IL-10 gene in IL-10KO mice resulted in a significant augmentation of apical diffusion of lanthanum after DNBS-induced colitis. Immunofluorescent labelling of frozen liver sections from DNBS-IL10KO mice, immunolocalization for and claudin- 1 and ZO- 1 resulted in a significant alteration in the localization of the immunosignals for claudin- 1 and ZO- 1 after DNBS administration in comparison with DNBS-IL10WT.

Conclusion: In conclusion, we suggest that the absence of IL-10 may represent an important pathophysiological mechanism of hepatobiliary injuries and cholestasis observed in patients with IBD.

\section{Introduction}

A variety of hepatobiliary abnormalities have been described in patients with chronic inflammatory bowel diseases (IBDs). The prevalence of abnormal liver function tests in patients with ulcerative colitis and Crohn's disease may be as high as $17 \%$ (1). It has long been known that serum total bilirubin and aminotransferase and alkaline phosphatase activities can be increased in patients with ulcerative colitis. (2). Histologically, analysis of liver biopsy specimens from patients with IBD can show inflammation of portal areas, cholangitis, and primary sclerosing colangitis. (3) The pathogenetic mechanisms responsible for hepatobiliary alterations in patients with IBD are not known. Several hypotheses have been proposed, including autoimmunity, genetic factors, and gut-derived bacteria antigens or toxins.

A number of animal models for IBD have been developed. The colitis can be observed in several

Address correspondence and reprint requests to: Salvatore Cuzzocrea, Institute of Pharmacology, School of Medicine, University of Messina, Torre Biologica - Policlinico Universitario Via C. Valeria - Gazzi - 98100 Messina, Italy. Phone: (39) 090 2213644, fax: (39) 0902213300 , e-mail: salvator@.unime.it. genetically engineered animal models that are created through targeted-gene deletion $(4,5)$.

Tight junctions between hepatocytes are the only intercellular barrier between the sinusoidal and the canalicular spaces. Tight junctions serve as a permeability barrier regulating the passage of ions and small molecules through the paracellular pathway (barrier function) and restrict the lateral diffusion of membrane lipids and proteins between the apical and basolateral compartments to maintain cell polarity (6-8). Tight junction shows a particular net-like meshwork of fibrils formed by the integral membrane proteins occludin (9), the claudin family $(10,11)$ and JAM (12). Several peripheral membrane proteins, ZO-1 (13), ZO-2 (14), ZO-3 (15), 7H6 antigen (16), cingulin (17), symplekin (18). The permeability of TJs can be modulated by a variety of substances and conditions, including bacterial toxins, $(19,20)$, polymorphonuclear leukocytes, (21) inflammatory cytokines, $(22,23)$ and estrogen (24-26).

During the inflammatory reaction, antiinflammatory cytokines are also produced and tend to modulate the inflammatory process. Interleukin-10 (IL-10) is a potent anti-inflammatory cytokine that 
inhibits the synthesis of the major pro-inflammatory cytokines and chemokines, upregulates humoral immune responses and attenuates cell-mediated immune reactions (27). Because of its properties, IL-10 has the ability to modulate several infectious, immune and inflammatory diseases. It has been demonstrated that genetic deficiency of IL-10 renders mice prone to spontaneous colitis (28) and more susceptible to develop a severe bacterial granulomatous pneumonitis (29). Recently it has been proposed that a breakdown of the hepatocyte $\mathrm{TJ}$ paracellular barrier is associated with intestinal inflammation and that it contributes to the pathogenesis of liver disease (30).

The purpose of this study was to investigate the role of endogenous IL-10 in alteration of hepatocyte $\mathrm{TJ}$ paracellular barrier and in the rapid transcytotic vesicular pathway modification associated with intestinal inflammation. To address this question, we used an experimental model of colitis, induced by dinitrobenzene sulfonic acid (DNBS), which has been widely used to reproduce and study intestinal inflammation $(31,32)$. After induction of colitis in mice IL-10KO, liver function was assessed by measurement of aminotransferase and alkaline phosphatase activities. The permeability of TJs in vivo was determined by measuring the biliary output of horseradish peroxidase (HRP) in perfused livers under single-pass conditions (33). In addition, semiquantitative analysis of the penetration of lanthanum nitrate into the junctional complexes and bile canalicular lumen (32) provided a morphological evaluation of the permselectivity of TJs. TJ structure was further assessed by immunofluorescent localization of the TJ proteins Claudin- 1 and ZO-1. In addition the rapid transcytotic vesicular pathway was quantified observing the HRP positive area over the total pericanalicular or perisinusoidal area as well as bile output. The results show that the genetic absence of IL-10 is associated with an significant increase in some serum markers of cholestasis and with a significant increase in hepatocyte TJ permeability. These observations suggest that endogenous IL-10 may play an antiinflammatory role in the hepatobiliary injury associated with IBD.

\section{Materials and Methods Animals}

C57BI-JlO mice (4-5 wk old, $2022 \mathrm{~g}$ ) with a targeted disruption of the IL-10 gene (IL-10 KO) and littermate wild-type controls (IL-10WT) were purchased from Jackson Laboratories (Bar Harbor, ME, USA). All animals were allowed access to food and water ad libitum. Animal care was in compliance with Italian regulations on protection of animals used for experimental and other scientific purpose (D.M. 116192) as well as with the EEC regulations (O.J. of E.C. L 358/1 12/18/1986)

\section{Induction of Experimental Colitis}

Colitis was induced with a very low dose of DNBS (4 mg per mouse) by using a modification (34) of the method first described in rats (31). Mice were anaesthetized by Enflurane. DNBS (4 mg in $100 \mu \mathrm{l}$ of $50 \%$ ethanol) was injected into the rectum through a catheter-inserted $4.5 \mathrm{~cm}$ proximally to the anus. Carrier alone (100 $\mu \mathrm{l}$ of $50 \%$ ethanol) was administered in control experiments. At day 4 after the beginning of DNBS treatment mice were anaesthetized by pentothal sodium administration (50 $\mathrm{mg} / \mathrm{kg}$ body wt intraperitoneally), and livers were perfused in situ (flow rate, $16-18 \mathrm{~mL} / \mathrm{min}$ ) with perfusion medium (Krebs'-Henseleit buffer, $\mathrm{pH}$ 7.4) containing $1 \%$ (wt/vol) bovine serum albumin, $5 \mathrm{mmol} / \mathrm{L} \mathrm{D}$-glucose, $1.2 \mathrm{mmol} / \mathrm{L} \mathrm{CaCl}_{2}$, amino acid mixture, and $20 \%$ (vol/vol) washed human erythrocytes (35). The perfusate was maintained at $37^{\prime} \mathrm{C}$ in a thermostatically controlled cabinet and was continuously gassed with $\mathrm{O}_{2} / \mathrm{CO}_{2}$ (19:1, vol/vol). The perfusion pressure was between 6 and $8 \mathrm{~cm} \mathrm{H20,} \mathrm{which} \mathrm{has} \mathrm{been} \mathrm{shown} \mathrm{not}$ to damage liver tissue. (36) The viability of perfused livers was assessed on the basis of the marked difference in colour between the afferent and efferent perfusates, the homogenity of liver surface, and the initial bile flow rates that were $>4 \mu \mathrm{L}-\mathrm{min}^{\prime}-100 \mathrm{~g}$ body wt and aspartate aminotransferase activity in the perfusate (36).

\section{Measurement of Cytokines}

TNF $\alpha$, IL- 6 and IL- $1 \beta$ levels were evaluate in colon and in the liver samples. The assay was carried out by using a colorimetric commercial kit (CalbiochemNovabiochem, La Jolla, CA, USA). The ELISA has a lower detection of $10 \mathrm{pg} / \mathrm{ml}$.

\section{Light Microscopy}

After fixation for $1 \mathrm{wk}$ at room temperature in Dietrich solution ( $14.25 \%$ ethanol, $1.85 \%$ formaldehyde, $1 \%$ acetic acid), Liver and colon samples were dehydrated in graded ethanol and embedded in Paraplast (Sherwood Medical, Mahwah, NJ, USA). Thereafter, $7-\mu \mathrm{m}$ sections were deparaffinized with xylene, stained with haematoxylin-eosin and trichromic van Giesson's stain, and observed in a Dialux 22 Leitz (Wetziar, Germany) microscope. Colon damage was scored by two independent observers as described previously $(37,38)$.

\section{Ultrastructural Study}

Electron Microscopy was carried out for evaluation of paracellular transport. Briefly, Livers were flushed with physiological solution before lanthanum perfusion fixation to clear liver tissue from blood and to prevent lanthanum precipitation. The perfusion/fixation solution was $2.5 \%$ glutaraldehyde/4\% lanthanum nitrate in $0.1 \mathrm{~mol} / \mathrm{L}$ cacodylate buffer, pH 7.8. After perfusion, livers were surgically 
excised, cut into fragments, and incubated in fixation solution $(2.5 \%$ glutaraldehyde in $0.1 \mathrm{~mol} / \mathrm{L}$ cacodylate buffer, $\mathrm{pH}$ 7.8). Tissue samples were rinsed for 30 minutes in $0.1 \mathrm{~mol} / \mathrm{L}$ cacodylate buffer and post fixed in 1\% osmium tetroxide for $\mathrm{l} \mathrm{hr}$ at $4^{\circ} \mathrm{C}$. Samples were then dehydrated by graded ethanol and embedded in Agar 100. Ten fragments from each animal $(\mathrm{CON}-$ mice, $\mathrm{n}=3$; DNBS-IL-10WT mice, $\mathrm{n}=3$, DNBS-IL-10KO mice, $\mathrm{n}=3$ ) were sectioned with an Ultramicrotome System 2128 (Ultratome, Bromme) ultramicrotome. Sections $(100 \mathrm{~nm})$ were examined at a magnification of $35,000 \mathrm{X}$ using a Hitachi H-600 electron microscope (Tokyo, Japan) operated at $50 \mathrm{kV}$. For morphological evaluation, bile canaliculi were scored as permeable to lanthanum when several particles were observed in the bile canaliculus lumen. Canaliculi in CON-livers were scored as negative when they contained no particles. The second evaluation (apical lanthanum) consisted of determining the number of cell-cell junctions where lanthanum was accumulated in the most apical region of the junction, e.g., infiltrating the junction to the canalicular lumen. This type of scoring was performed on junctions in which the plane of section was such that the accumulation of tracer was most confidently occurring apically with respect to the position of TJs. Observations were performed on number-coded specimens to avoid observer bias.

\section{Measurement of Biliary HRP}

Measurement of Biliary HRP output was carried out for evaluation of trancellular transport. To study the pattern of biliary HRP excretion, livers were perfused for an initial 30min under recycling conditions. Livers were then converted to single-pass conditions and $25 \mathrm{mg}$ of HRP (dissolved in $1 \mathrm{ml}$ of BSA- and erythrocyte-free perfusion medium) were infused from a syringe pump over a $1 \mathrm{~min}$ period into the perfusion line just prior to the portal cannula. After a further $5 \mathrm{~min}$, recycling perfusion was restored until the end of the experiment. Bile was collected as six 5 -min samples during the $30-\mathrm{min}$ stabilization period and then as five 2-min samples followed by eight 5 -min samples. Bile flow rates were determined gravimetrically assuming that bile has a density of $1 \mathrm{~g} / \mathrm{ml}$.

To study rapid transcytotic vesicular pathways, Imin pulses of HRP $(500 \mathrm{mg})$ was given after 30 min of recycling perfusion according to Hayakawa et al (39). After 2 min of single-pass perfusion, the livers were fixed by perfusion for 2 min with $2.5 \%(\mathrm{w} / \mathrm{v})$ glutaraldehyde, $0.8 \%(\mathrm{w} / \mathrm{v})$ paraformaldehyde in $0.1 \mathrm{M}$ cacodylate buffer, $\mathrm{pH}$ 7.8. After the perfusion fixation, liver tissue was cut into $\mathrm{lmm}^{3}$ fragments and further immersed in the same fixative for $2 \mathrm{hr}$. Subsequently, fragments were rinsed for $30 \mathrm{~min}$ in $0.1 \mathrm{M}$ cacodylate buffer, $\mathrm{pH} 7.8$, containing $0.1 \mathrm{M}$ sucrose. HRP activity was examined in liver samples using the 3,3'-diaminobenzidine technique of Graham and Karnovsky (20). The specimens were incubated in a saturated solution of 3,3-diaminobenzidine in $0.05 \mathrm{M}$ Tris $\mathrm{HCl} \mathrm{pH} \mathrm{7.6,}$ containing $0.01 \%(\mathrm{v} / \mathrm{v}) \mathrm{H}_{2} \mathrm{O}_{2}$. The liver samples were washed in $0.1 \mathrm{M}$ Tris $\mathrm{HCl}$ buffer, $\mathrm{pH}$ 7.6, then in $0.1 \mathrm{M}$ cacodylate buffer, $\mathrm{pH} 7.8$, and post fixed for $45 \mathrm{~min}$ at $4^{\prime} \mathrm{C}$ in $1 \%(\mathrm{w} / \mathrm{v})$ osmium tetroxide containing $1 \%(\mathrm{w} / \mathrm{v})$ potassium ferrocyanide. Finally, the fragments were dehydrated and processed for embedding in Epon 812. Ultrathin sections were stained with lead citrate and examined in a Hitachi H-600 transmission electron microscope at $75 \mathrm{~W}$. After 15 min of recycling perfusion, taurodehydrocholate (TDHQ) was coinfused into the portal vein at a constant rate of $1 \mathrm{~mol} / \mathrm{min}$ until the end of the experiment. TDHC has been shown to restore the bile flow rate during the assessment of hepatic tight junction permeability (40). Furthermore, TDHC does not affect the transcytotic vesicular pathway (39).

Morphometric analysis were carried out on ten electron micrographs obtained from the pericanalicular (PC) and perisinusoidal (PS) areas of each liver at an initial magnification of $7500 \mathrm{X}$ and were printed at a final magnification of $15,0000 \mathrm{X}$. On each electron micrograph, a 1 -gm' $^{\prime}$ area around the canalicular and basolateral membrane was delimited. The bile canalicular space and microvilli were excluded. The total pericanalicular and perisinusoidal area of each HRP-containing structure were quantified with the Ibas Kontron semiautomatic analyser. The results are expressed as the percentage of HRP positive area over the total pericanalicular or perisinusoidal area.

\section{Immunofluorescence}

Indirect immunofluorescence staining was performed on $7 \mu \mathrm{m}$-thick sections of unfixed mice liver. Sections were cut in with a cryostat at $-27^{\circ} \mathrm{C}$,

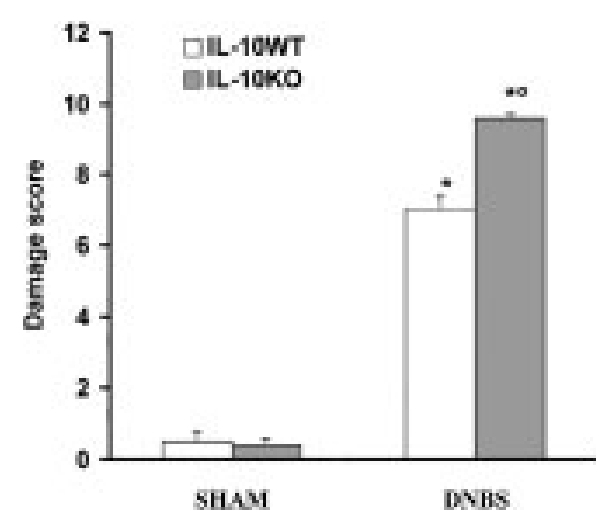

Fig. 1. Effects of IL-10 on the macroscopic damage score. Colon damage was scored by two independent observers. Data are means \pm SEM of 10 mice for each group. ${ }^{*} \mathrm{P}<0.01$ versus vehicle. ${ }^{\circ} \mathrm{P}<0.01$ represents significant increase of the various parameters in the group in which IL-10 was absent. 
transferred onto clean glass slides, and dried overnight at room temperature. Sections were fixed with acetone, and rehydrated in phosphatebuffered saline (PBS) and incubated with rabbit polyclonal anti-claudin-1 antibody (1:100 in PBS, vol/vol) (Zimed, Milan, Italy) or with rabbit polyclonal anti-ZO-1 antibody (1:500 in PBS, v/v;
Zymed Laboratories) in a humidified chamber for $\mathrm{l} \mathrm{hr}$ at $37^{\circ} \mathrm{C}$. Sections were washed with PBS and incubated with secondary antibody (anti-rabbit Texas-red conjugate antibody $(1: 100$ in PBS, $\mathrm{vol} / \mathrm{vol}$ ) for $1 \mathrm{hr}$ at $37^{\circ} \mathrm{C}$. Sections were washed as before, mounted with $90 \%$ glycerol in PBS, and observed with a LSM 510 Zeiss laser confocal

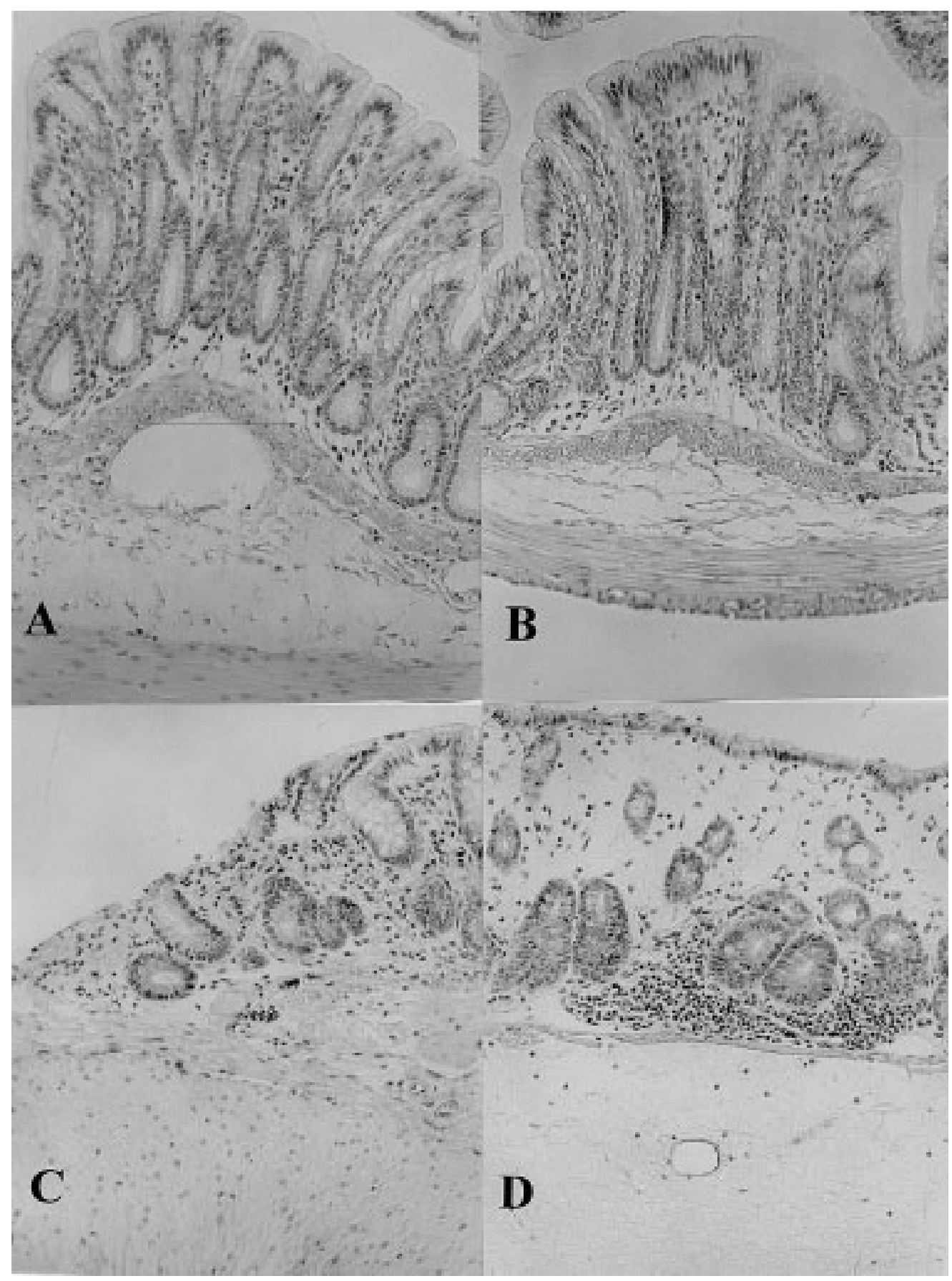

Fig. 2. Morphologic changes of colon. Representative trichromic van Giesson's stain-stained section of colon were examined by light microscopy in normal control IL-10WT (A) and IL-10KO (B) mice not given DNBS, in IL-10 wild-type mice given DNBS (C) and in IL-10KO mice given DNBS (D). Original magnification: $\times 125$. Figure is representative of at least 3 experiments performed on different experimental days. 


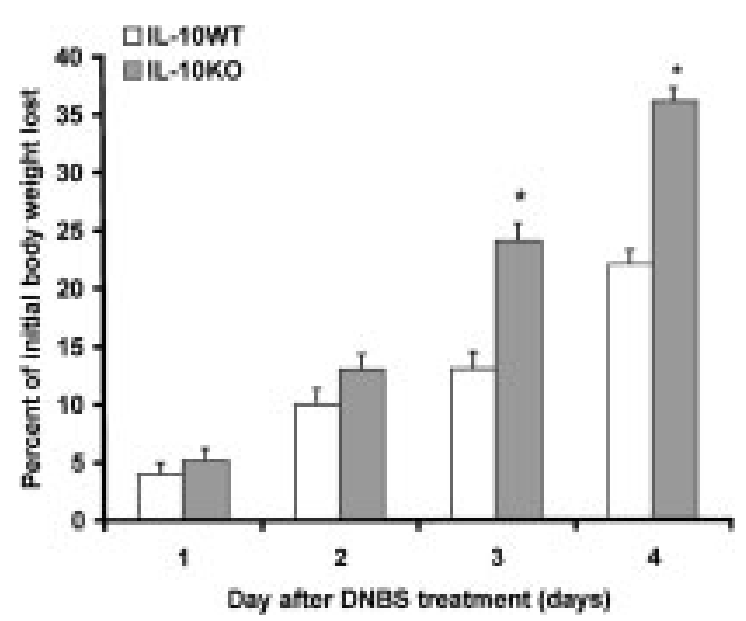

Fig. 3. Effect of IL-10 on body weight changes after DNBS intracolonic administration. Body weight was recorded immediately before DNBS during the experimental period. Absence of IL-10 significantly increases the DNBS-induced increase in body weight lost. Data are means \pm SEM of 10 mice for each group. ${ }^{*} \mathrm{P}<0.01$ versus vehicle. ${ }^{\circ} \mathrm{P}<0.01$ represents significant increase of the various parameters in the group in which IL-10 was absent.

microscope equipped with a $40 \mathrm{X}$ oil objective. Images were recorded on disk, color-reversed so that fluorescence (white) appeared black, transferred onto slide film and printed from the slide.

\section{Metabolic Changes}

Plasma levels of bilirubine and alanine aminotransferase were determined by a clinical laboratory.

\section{Materials}

Lanthanum, nitrate (relative molecular mass, 433.02), glutaraldehyde, osmium tetroxide, and cacodylate buffer were from Societa' Italiana Chimici (Rome, Italy). Agar 100 was purchased from Agar Scientific, Ltd (Stansted, England). DNBS, HRP (relative molecular mass, 40,000) type II, bovine serum albumin type $\mathrm{V}$, L-amino acids, D-glucose, ortho-dianisidine, and common laboratory reagents were purchased from Sigma Chemical Co. (St. Louis, MO, USA). Human blood was obtained from the Padova Hospital Transfusion Unit.

\section{Data Analysis}

All values in the figures and text are expressed as mean \pm standard error (sem.) of the mean of $n$ observations. For the in vivo studies $n$ represents the number of animals studied. In the experiments involving histology or immunohistochemistry, the figures shown are representative of at least three experiments performed on different experimental days. The results were analysed by one-way ANOVA followed by a Bonferroni post-hoc test for multiple comparisons. A $p$-value less of than 0.05 was considered significant.

\section{Results}

Effects of Endogenous IL-10 on the Degree of Colitis (Histology and General Assessment)

Four days after intra-colonic administration of DNBS, the colon appeared flaccid and filled with liquid stool. The macroscopic inspection of cecum, colon and rectum showed presence of mucosal congestion, erosion and hemorrhagic ulcerations (see damage score Fig. 1). The histopathological features included a transmural necrosis and oedema and a diffuse leukocyte cellular infiltrate in the submucosa of colon section from DNBS-treated IL-10WT mice (Fig. 2, C). The absence of IL-10 significantly increases the extent and severity of the histological

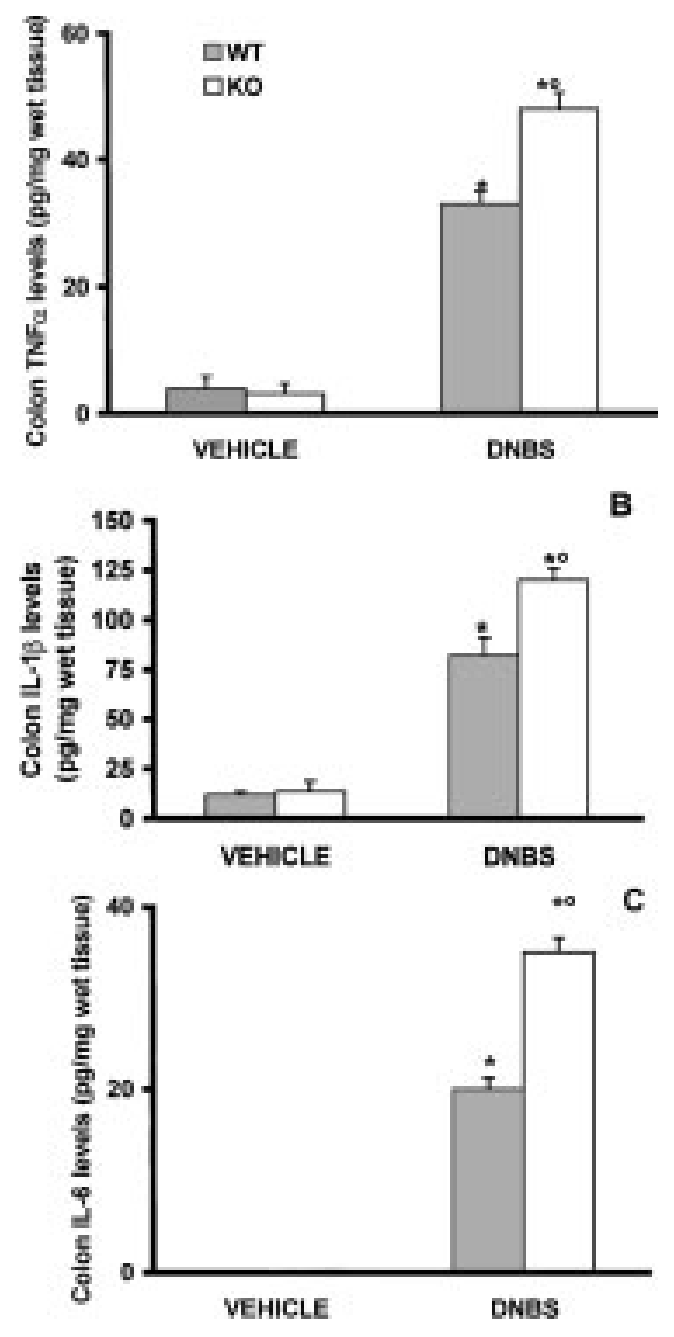

Fig. 4. Colon TNF $\alpha$, ILI $\beta$ and IL-6 production at 4 days after DNBS administration. (A) $\mathrm{TNF} \alpha$, (B) ILl $\beta$ and (C) IL-6 colon levels. IL-10WT mice show a significant production of cytokines at 4 days after DNBS administration. Cytokine levels were significantly enhanced in IL-10KO mice. No IL-10 production was found in plasma from IL-10KO mice. Data are means \pm SEM of 10 mice for each group. ${ }^{*} \mathrm{P}<0.01$ versus vehicle. ${ }^{\circ} \mathrm{P}<0.01$ represents significant increase of the various parameters in the group in which IL-10 was absent. 
signs of colon injury (Figs. 1, 2-D). Four days after colitis induced by DNBS treatment, all mice had diarrhoea and a significant reduction in body weight (compared with the control groups of mice) (Fig. 3). Absence of a functional IL-10 gene in IL-10KO mice resulted in a significant augmentation of lost of body weight (Fig. 3). No histological alteration was observed in the colon tissue from vehicletreated IL-10WT and IL-10KO mice (Fig. 2, A-B, respectively).

Endogenous IL-10 Modulates Production of TNF- $\alpha, I L-6$ and $I L-1 \beta$ after DNBS Administration

To test whether endogenous IL-10 may modulate the inflammatory process through the regulation of the secretion of other cytokines, we analysed the colon and liver levels of pro-inflammatory cytokines TNF- $\alpha$, IL- 6 and IL- $1 \beta$ in IL-10KO and wild-type mice. A substantial increase of TNF- $\alpha$, IL- $1 \beta$ and IL-6 formation was found in colon and liver samples collected from IL-10WT mice at $4 \mathrm{~d}$ after DNBS administration (Figs. 4, 5). Colon and liver levels of TNF- $\alpha$, IL- 6 and IL- $1 \beta$ were significantly higher in IL-10 deficient mice in comparison to those of IL-10WT animals (Figs. 4, 5).

\section{Liver Histology and Biochemical Parameters}

Liver histology from IL-10KO and wild-type mice IL-10WT did not show any parenchymal and portal tract inflammation at $4 \mathrm{~d}$ after DNBS administration (Fig. 6, C-D). Serum total bilirubin and Alanine aminotransferase, were significantly increased in DNBS-IL-10WT mice vs. vehicle-mice (Table 1). Absence of a functional IL-10 gene in IL10KO mice resulted in a significant augmentation of serum total bilirubin total and alanine aminotransferase production after DNBS-induced colitis.
No histological alteration was observed in the liver tissue from vehicle-treated IL-10WT and IL-10KO mice (Fig. 6, A-B, respectively)

\section{Lanthanum Permeability}

Electron microscopic evaluation of the penetration of lanthanum, an electron-dense heavy metal tracer, across the junction has been used to assess the permeability of hepatocyte TJs. (41). We determined the accumulation of lanthanum in the most apical area of the junction. In livers from vehicle-treated WT mice (Fig. 7, A) or from vehicle-treated IL-10KO mice (Fig. 7, B), lanthanum accumulation is arrested at a position at some distance from the bile canaliculus lumen, suggesting that normal TJs prevent apical diffusion of lanthanum. Instead, in livers from DNBStreated IL-10WT mice, lanthanum accumulated throughout the junctional area up to the most apical region bordering the lumen (Fig. 7, C). Absence of a functional IL-10 gene in IL-10KO mice resulted in a significant augmentation of apical diffusion of lanthanum (Fig. 7, D) after DNBSinduced colitis. Quantitative analysis of lanthanum accumulation in the junctions showed that apical accumulation occurred in $59.78 \%$ of junctions of livers from DNBS-treated IL-10WT mice and in $6.3 \%$ of sham IL-10WT livers (see Fig. 8, A). A more pronounced lanthanum accumulated throughout the junctional area up to the most apical region bordering the lumen was observed in the liver from DNBS-treaded IL-10KO mice (92.8\%; Fig. 8, A). Lanthanum permeability was also assessed by determining the percentage of bile canaliculi that contained lanthanum particles (41; see Fig. 8, B). Using this criterium, sham IL-10WT livers showed $1.92 \%$ of bile canaliculi

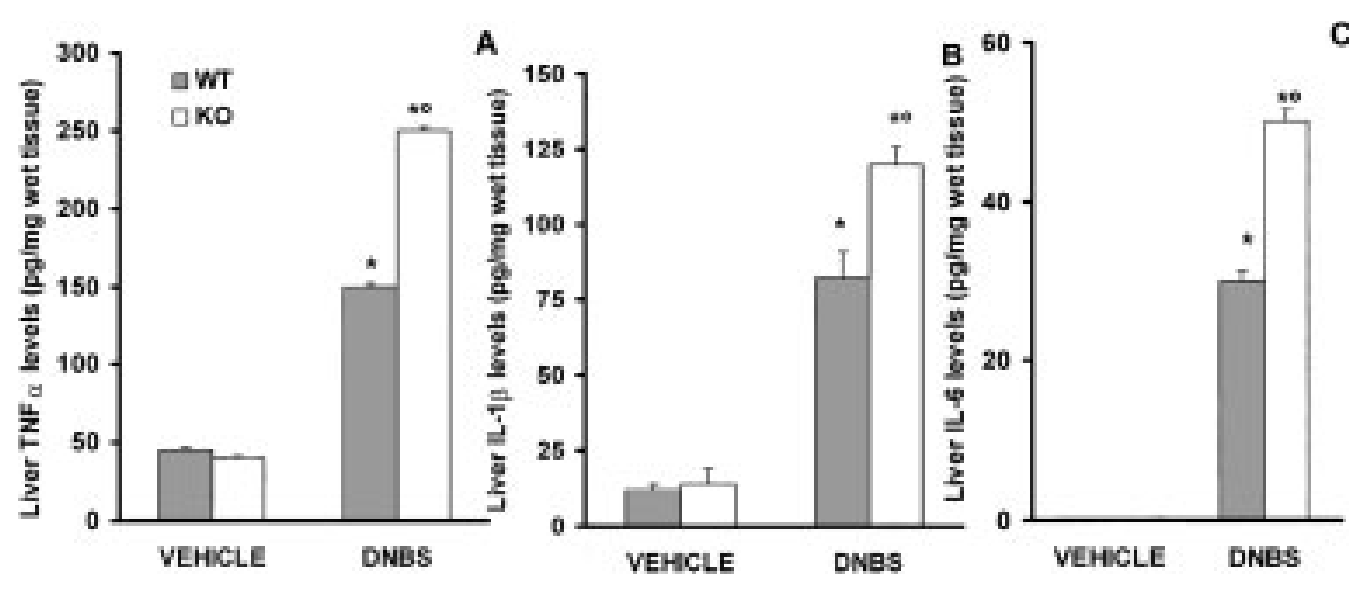

Fig. 5. Liver TNF $\alpha$, ILI $\beta$ and IL-6 production at 4 days after DNBS administration. (A) TNF $\alpha$, (B) ILl $\beta$ and (C) IL-6 liver levels. IL-10WT mice show a significant production of cytokines at 4 days after DNBS administration. Cytokine levels were significantly enhanced in IL-10KO mice. No IL-10 production was found in plasma from IL-10KO mice. Data are means \pm SEM of 10 mice for each group. ${ }^{*} \mathrm{P}<0.01$ versus vehicle. ${ }^{\circ} \mathrm{P}<0.01$ represents significant increase of the various parameters in the group in which IL-10 was absent. 
with lanthanum particles ( $\mathrm{n}=8$; canaliculi scored), DNBS-IL10WT livers showed $39.9 \%$ positive canaliculi ( $\mathrm{n}=8$; canaliculi scored) whereas DNBS-IL-10KO mice showed $98.8 \%$ positive canaliculi ( $\mathrm{n}=8$; canaliculi scored). In summary, morphological evaluation of hepatocyte TJs using two distinct parameters of scoring indicated an increased permeability of hepatocyte TJs. Increased permeability that was more pronounced in IL10KO mice.

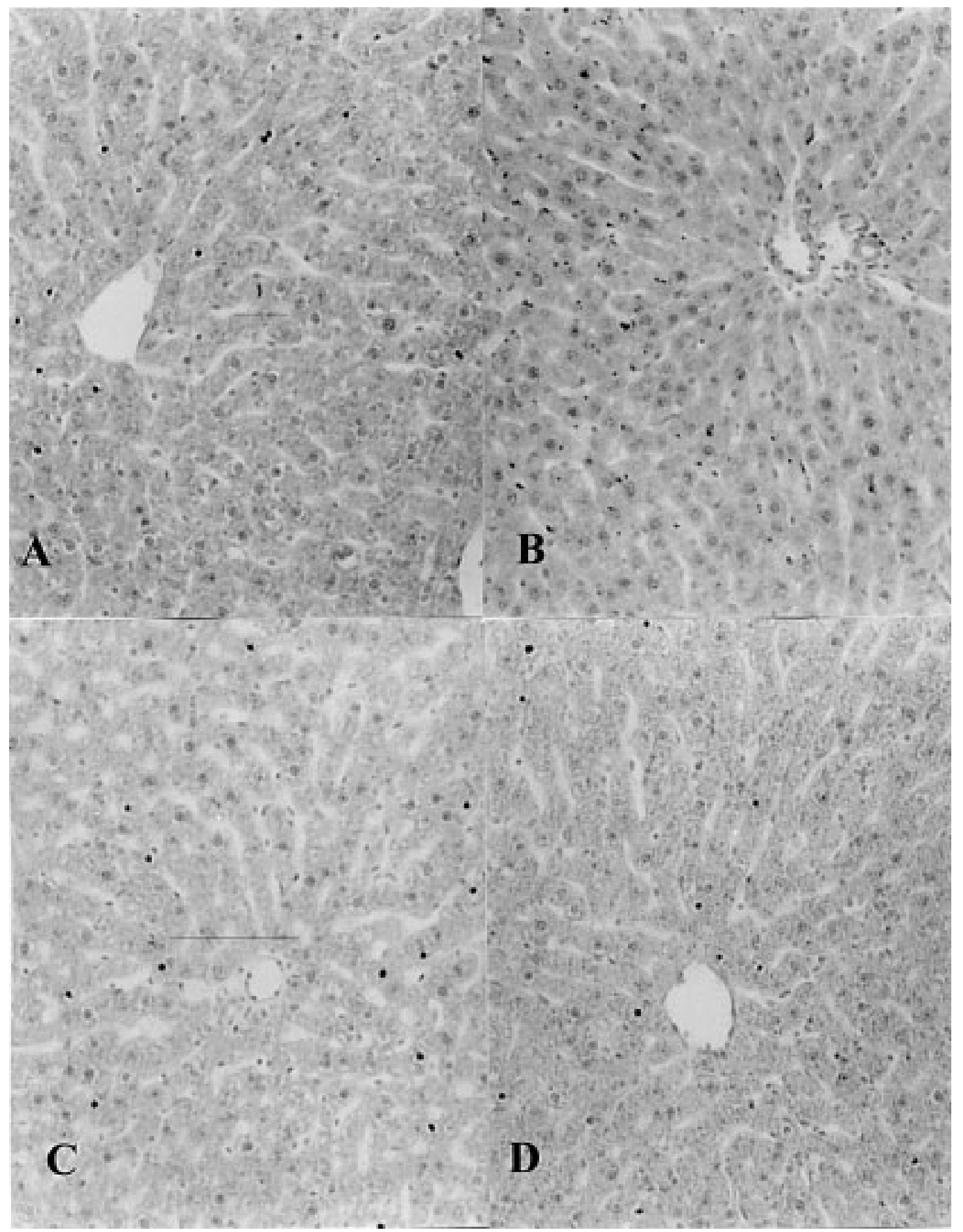

Fig. 6. Morphologic changes of Liver. Representative section of liver were examined by light microscopy in normal control IL-10WT (A) and IL-10KO (B) mice not given DNBS, in IL-10 wild-type mice given DNBS (C) and in IL-10KO mice given DNBS (D). Original magnification: $\times 125$. Figure is representative of at least 3 experiments performed on different experimental days. 
Table 1 Effect of IL-10 on liver function

\begin{tabular}{lcc}
\hline & $\begin{array}{c}\text { Bilirubine Tot } \\
(\mu \mathrm{mol} / \mathrm{L})\end{array}$ & $\begin{array}{c}\text { ALT } \\
(\mathrm{U} / \mathrm{L})\end{array}$ \\
\hline IL-10WT + Vehicle & $0.1 \pm 0.01$ & $18 \pm 4$ \\
IL10KO + Vehicle & $0.05 \pm 0.01$ & $17 \pm 5$ \\
IL-10WT + DNBS & $0.31 \pm 0.02^{*}$ & $29 \pm 3^{*}$ \\
IL10KO + DNBS & $0.48 \pm 0.09^{* \circ}$ & $39 \pm 2^{*}$ \\
\hline
\end{tabular}

Data are means \pm s.e. means of 10 mice for each group.

${ }^{*} \mathrm{P}<0.01$ versus IL-10sham. ${ }^{*} \mathrm{P}<0.01$ versus vehicle. ${ }^{\circ} \mathrm{P}<0.01$

represents significant reduction of the various parameters in the group in which IL-10 was absent.
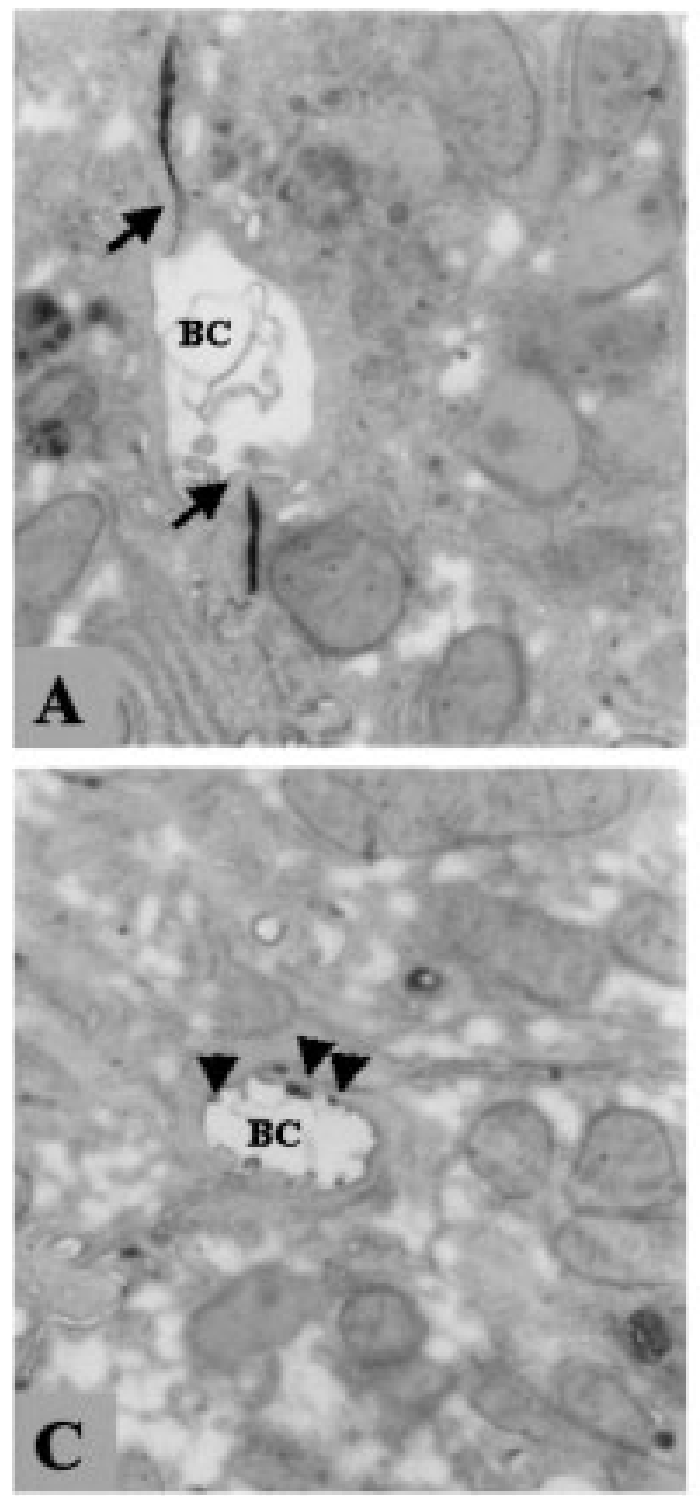

\section{HRP Excretion Pattern}

To test whether endogenous IL-10 may modulate the paracellular pathway and rapid transcellular pathway during inflammatory, we analysed the first HRP peak. A significantly $(P<0.05)$ increased of the HRP output was observed in the liver from DNBS-treated IL-10WT mice. Levels of HRP output were significantly higher in IL-10 deficient mice in comparison to those of IL-10WT animals (Fig. 9). Therefore a high dose of HRP (500 mg) was infused as a 1-min pulse, the percentage area of the pericanalicular and perisinusoidal HRP containing structure obtained at 2 min was not significantly in livers from the different experimental groups (Fig. 10).
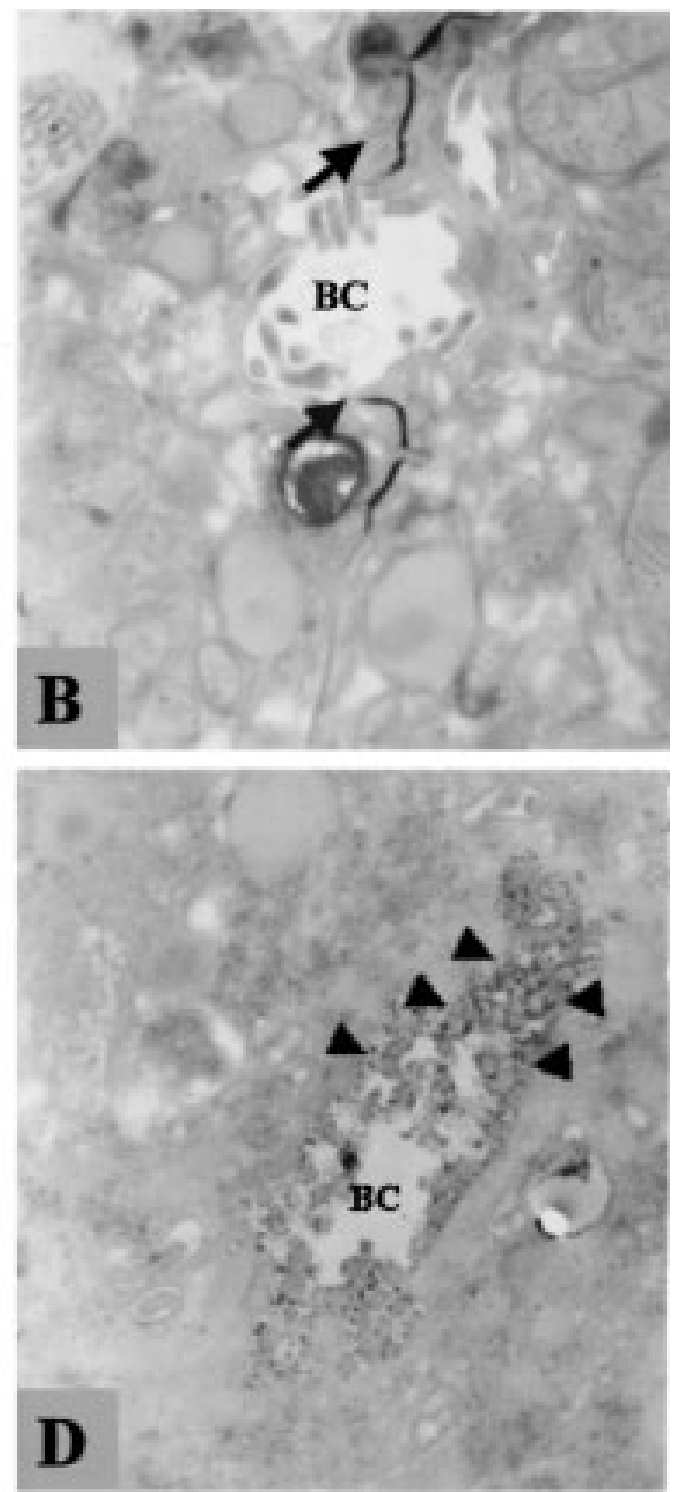

Fig. 7. Electron micrographs. Section of sham-IL10WT mice (A), sham-IL10KO mice (B), DNBS-IL10WT mice (C) and DNBSIL10KO mice (D). Arrows in A indicate the presumptive TJ area that limits accumulation of lanthanum. Arrowhead in B and C indicates lanthanum particles in the canalicular lumen (BC: bile canaliculus). 

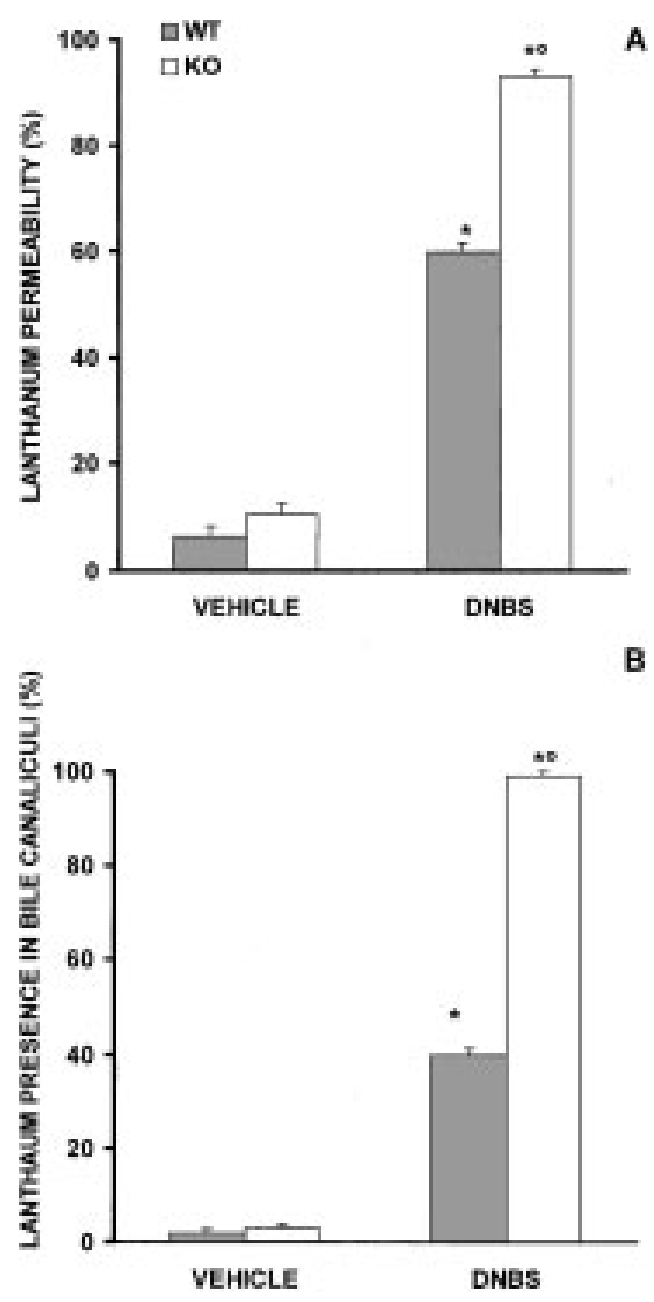

Fig. 8. Quantitative analysis of apical (A) and bile canaliculi (B) lanthanum accumulation. Absence of IL-10 significantly increases the DNBS-induced lanthanum accumulation. Data are means \pm SEM of 10 mice for each group. ${ }^{*} \mathrm{P}<0.01$ versus vehicle. ${ }^{\circ} \mathrm{P}<0.01$ represents significant increase of the various parameters in the group in which IL-10 was absent.

\section{Claudin-1 and ZO-1Immunolocalization}

Immunofluorescent labelling of frozen liver section from vehicle-treated WT mice (Fig. 11, A) or from vehicle-treated IL-10KO mice (Fig. 11, B) with anti-Claudin-1 antibody showed that, in longitudinal sections of canaliculi, the protein is distributed uniformly and continuously along two parallel lines bordering the canaliculus. In DNBS-IL10WT mice, immunolocalization for and claudin-1 (Fig. 11, C) was modified in comparison with sham-IL10WT mice. Absence of a functional IL-10 gene in IL-10KO mice resulted in a significant alteration in the localization of the immunosignals for claudin-1 (Fig. 11, D) after DNBS administration.

Similarly, as shown in Figure 12, a significant disruption of immunofluorescence signal for ZO-1 (C) was observed in the liver section obtained

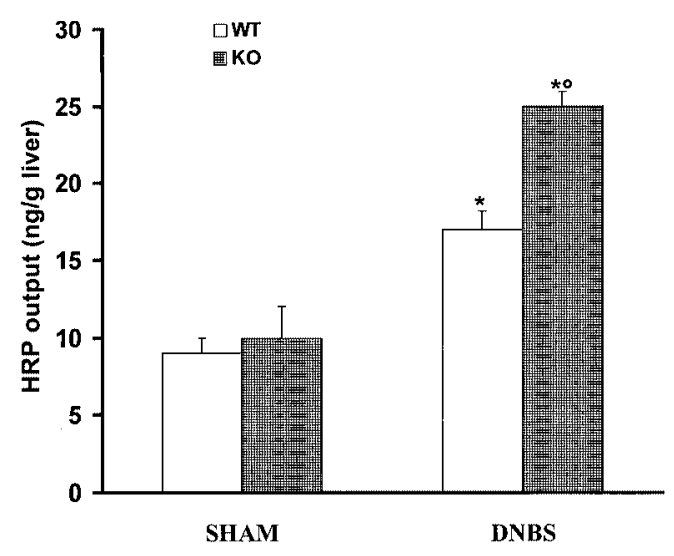

Fig. 9. HRP bile output. Absence of IL-10 significantly increases the DNBS-induced HRP bile output. Data are means \pm SEM of 10 mice for each group. ${ }^{*} \mathrm{P}<0.01$ versus vehicle. ${ }^{\circ} \mathrm{P}<$ 0.01 represents significant increase of the various parameters in the group in which IL-10 was absent.

from DNBS-treated WT mice. In liver fragment from DNBS-treated IL-10KO mice was found a more significant irregular distribution pattern of ZO-1 (D) and $\beta$-catenin (C-2). Immunofluorescent labelling of frozen liver section from vehicletreated WT mice (Fig. 12, A) or from vehicletreated IL-10KO mice (Fig. 12, B) with anti-ZO-1 antibody showed that the protein is distributed uniformly and continuously.

\section{Discussion}

The objective of the present study was to investigate the role of IL-10 on the hepatic TJ permeability alteration during DNBS-induced experimental colitis. In the present study we have observed that the increase in serum bilirubin (bilirubin monoglucuronide) and bile acids, markers of cholestasis during DNBS-induced colitis was significantly higher in IL-10KO mice in comparison to the correspondent WT mice.

Base on these results we hypothesized that IL-10 plays a role in the modulation of hepatic TJs perselectivity. Cholestasis has been observed in a rat model of IBD induced by intracolonic injection of TNB (30). Our data demonstrate that the increase of the first peak of biliary HRP is significantly higher in the IL-10KO mice in comparison to the IL-10WT mice indicating that tight junctions are more permeable in the absence of IL-10. The results were confirmed by the quantitative analysis of lanthanum accumulation in the TJs of the bile canaliculi. In addition, HRP excretion reflects functional permeation rate, whereas lanthanum indicates structural permeation sites. The increase in the permeability of TJs well correlated with disruption of the junctional complexes, as shown by the immunofluorescent localization of the TJ proteins Claudin-1, which in DNBS liver from IL-10KO 


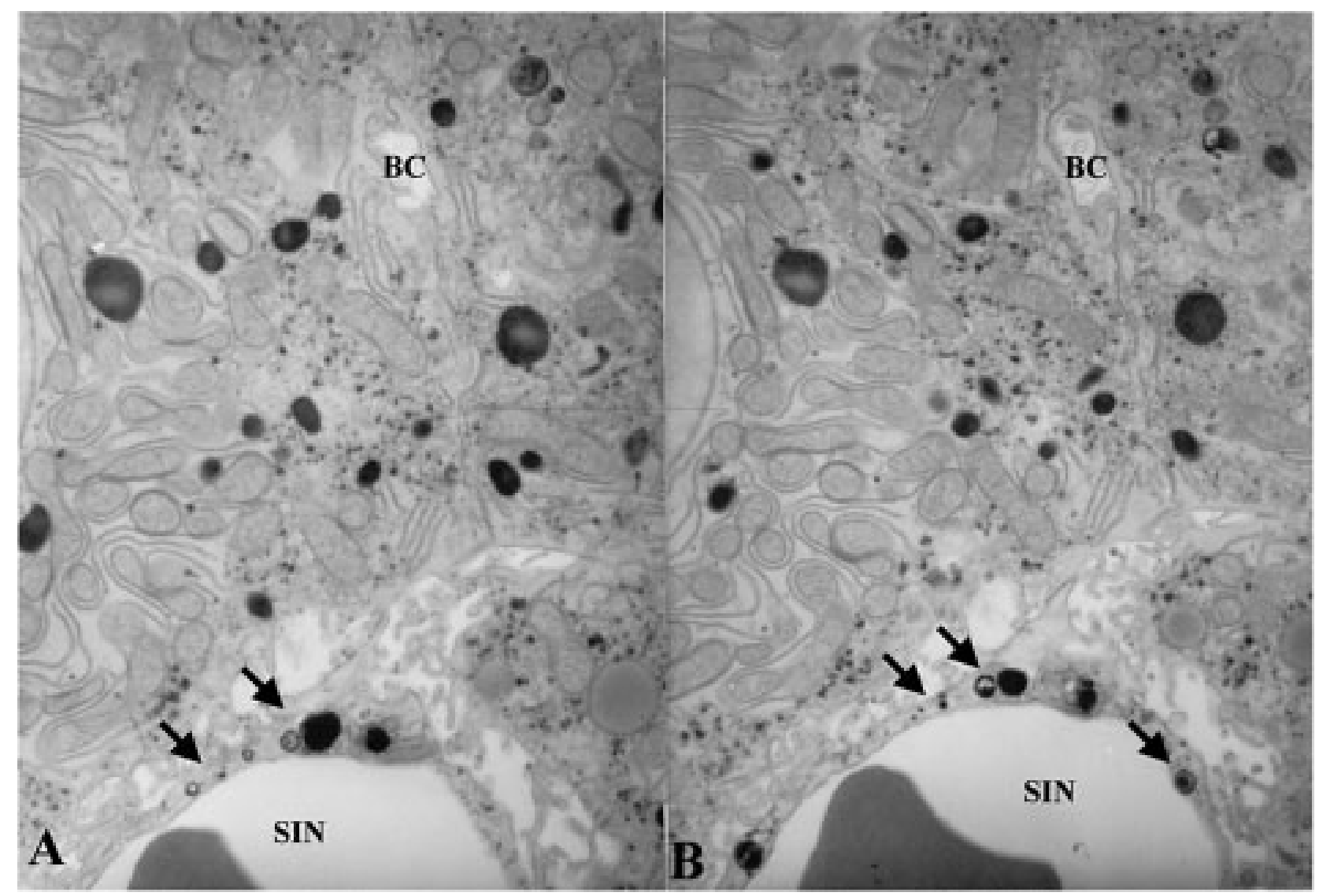

Fig. 10. Electron micrographs. DNBS-IL10WT (A) and DNBS-IL10KO (B) mice liver samples taken 2 min after a 1-min pulse of HRP (500 mg). Arrows indicate HRP-containing structures in pericanalicular and perisinusoidal areas (BC: bile canaliculus, SIN: sinusoidal space).

mice was significantly damaged in comparison to the IL-10WT mice. Recently studies have demonstrated that immunostaining for the TJ-associated proteins, ZO-1 $(30,42)$ and cingulin $(30)$ is not changed in hepatocytes of TNB rats.

In contrast, recently it has been found that the immunoistochemistry for $7 \mathrm{H} 6$ diminished at the border of the bile canaliculi and immunolocalization was spread to the submembranous cytoplasm showing dissociation in localization of $7 \mathrm{H} 6$ and $\mathrm{ZO}-1$ at hepatocyte (42).

Recent studies have demonstrated an important role of ZO-1 in structural and functional organization of tight junctions. In addition Fanning and colleagues (43) have demonstrated that $\mathrm{ZO}-1$ bind to carboxy-tail of occludin, via an $\mathrm{NH}_{2}$ terminal domain, and actin via $\mathrm{COOH}$-terminal domain, thus acting as a bridge, between plasma membrane and cytoskeleton proteins. These studies suggest that the targeting of claudin to tight junctions is dependent on an interaction with ZO- 1 and that ZO- 1 appears to play an active role in maintaining the proper subcellular localization of claudin to the tight junctions (44). This allows us to suggest that ZO- 1 reduction in DNBS-treated WT mice may impair claudin binding at the membrane with a resultant decrease in membranous claudin staining. Therefore, we have demonstrated that this alteration is significantly more evident in the hepatocyte from DNBS-treated IL-10KO mice. Thus, in the present study the redistribution of TJ protein(s) seems to be correlated to the presence of IL-10. The possibility that $\mathrm{TJ}$ alterations may be caused by a toxic effect of DNBS on hepatocytes is unlikely because endoportal administration of DNBS or ethanol produced minor changes in lanthanum permeability of junctions (30). First, chronic portal bacteraemia observed in rats with experimental colitis could act by stimulating macrophages and Kuppfer's cells in the liver to produce a wide range of cytokines. Cytokines are known to modulate TJ function (30,45-47). Indeed, endotoxinemia and pro-inflammatory cytokines have been known to affect the function of TJ (48-51). We confirm here that the inflammatory process (DNBS-induced colitis) leads to a substantial increase in the levels of pro-inflammatory cytokines in the colon and in the liver (Figs. 4, 5). Originally, interleukin 10 was described as a cytokine synthesis inhibitory factor produced by murine Th2 cell clones that could 
inhibit the synthesis of interferon-g by Th, clones (52-55). Recent studies have demonstrated that IL-10 can inhibit the synthesis of the major proinflammatory cytokines and chemokines, upregulates humoral immune responses and attenuates cell-mediated immune reactions (56-60). Interestingly, because of its properties, IL-10 has the ability to modulate several infectious, immune and inflammatory diseases. To prove the crucial role of IL-10 in controlling the inflammatory responses during experimental colitis, previous experimental studies have depended on in vivo administration of exogenous IL-10 and using IL-10KO mice (61-64). In our study, using genetically engineered mice, we have demonstrated that the endogenous production of IL-10 has a significant role in determining the outcome of colitis, as well as hepatic function. Thus, our findings confirm that the small intestine of young IL-10KO mice is more susceptible to inflammatory stimuli such as experimental colitis. In fact
IL-10KO mice are used as a model of spontaneous inflammatory bowel disease (59), in the young IL10KO mice used for our experiments, the damage appeared to be secondary to the DNBS intracolonic administration since sham mice did not exhibit any histological or clinical signs of colon inflammation. In agreement with our data, it is well known that deficiency of IL-10KO mice developed intestinal diseases, such as colitis, in conditions of age related-stress and changes in bacterial colonization $(59,65)$.

In conclusion, we documented that IL-10 modulate during experimental bowel disease: (1) the functional alteration of permselectivity of hepatocyte TJ; (2) the alteration of tranmembrane dominie of hepatocyte TJ; (3) pro-inflammatory cytokine production and (4) development of cholestasis. We suggest that this may represent an important pathophysiological mechanism of hepatobiliary injuries and cholestasis observed in patients with IBD.
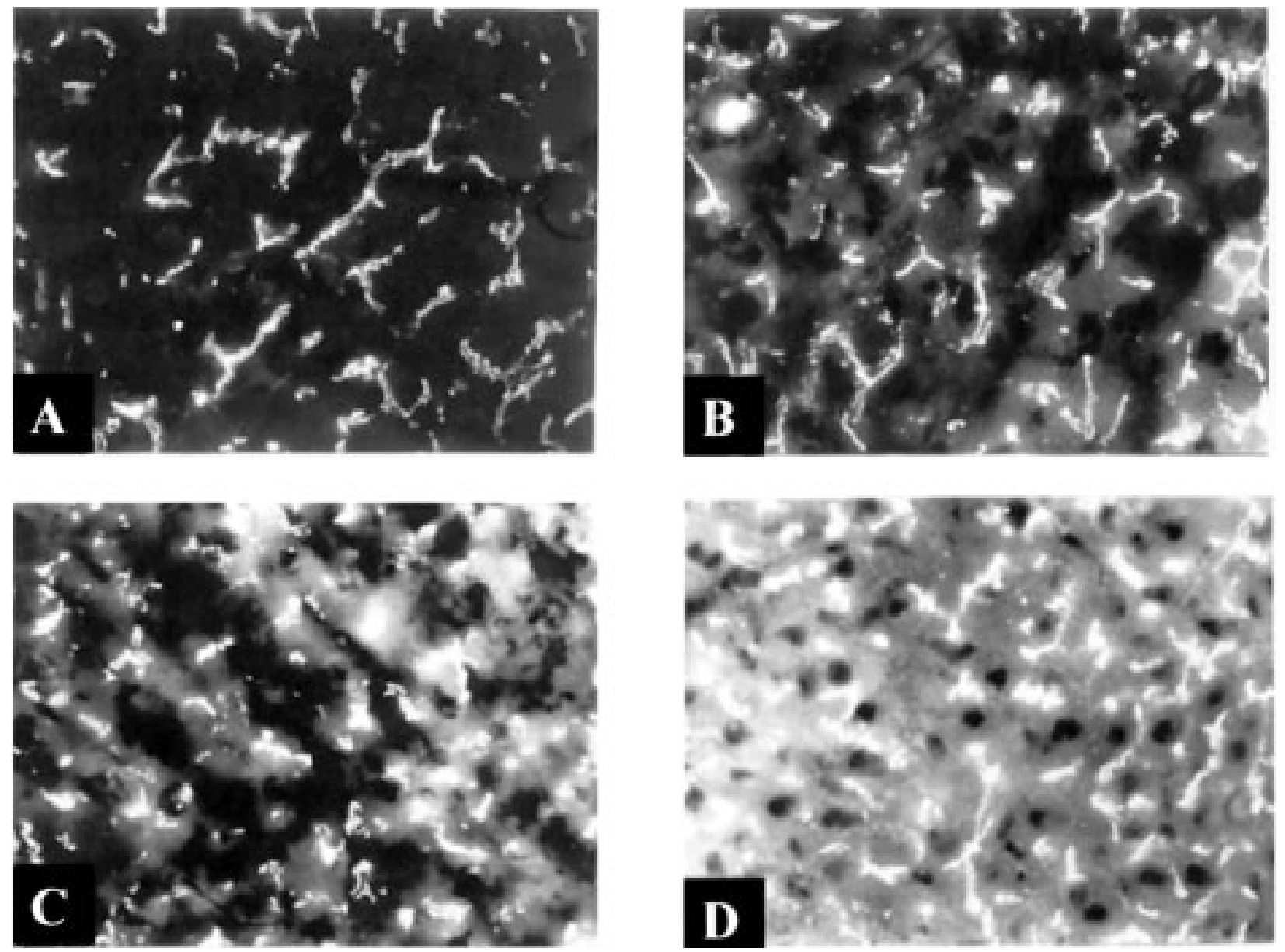

Fig. 11. Confocal laser scanning microscopic images. Claudin-1 in sham-IL10WT mice (A), sham-IL10KO mice (B), DNBS-IL10WT mice (C) and DNBS-IL10KO mice (D). Immunostaining for Claudin-1 was localized bordering the bile canaliculi (A), appearing as two parallel thin continuous lines. In DNBS-ILlOWT mice (C) the distribution of the protein was modified in comparison with sham-IL10WT mice. In contrast, the immunohistochemical localization of the claudin-1 in section of liver from DNBS-IL10KO mice was irregular and discontinuous (D). 

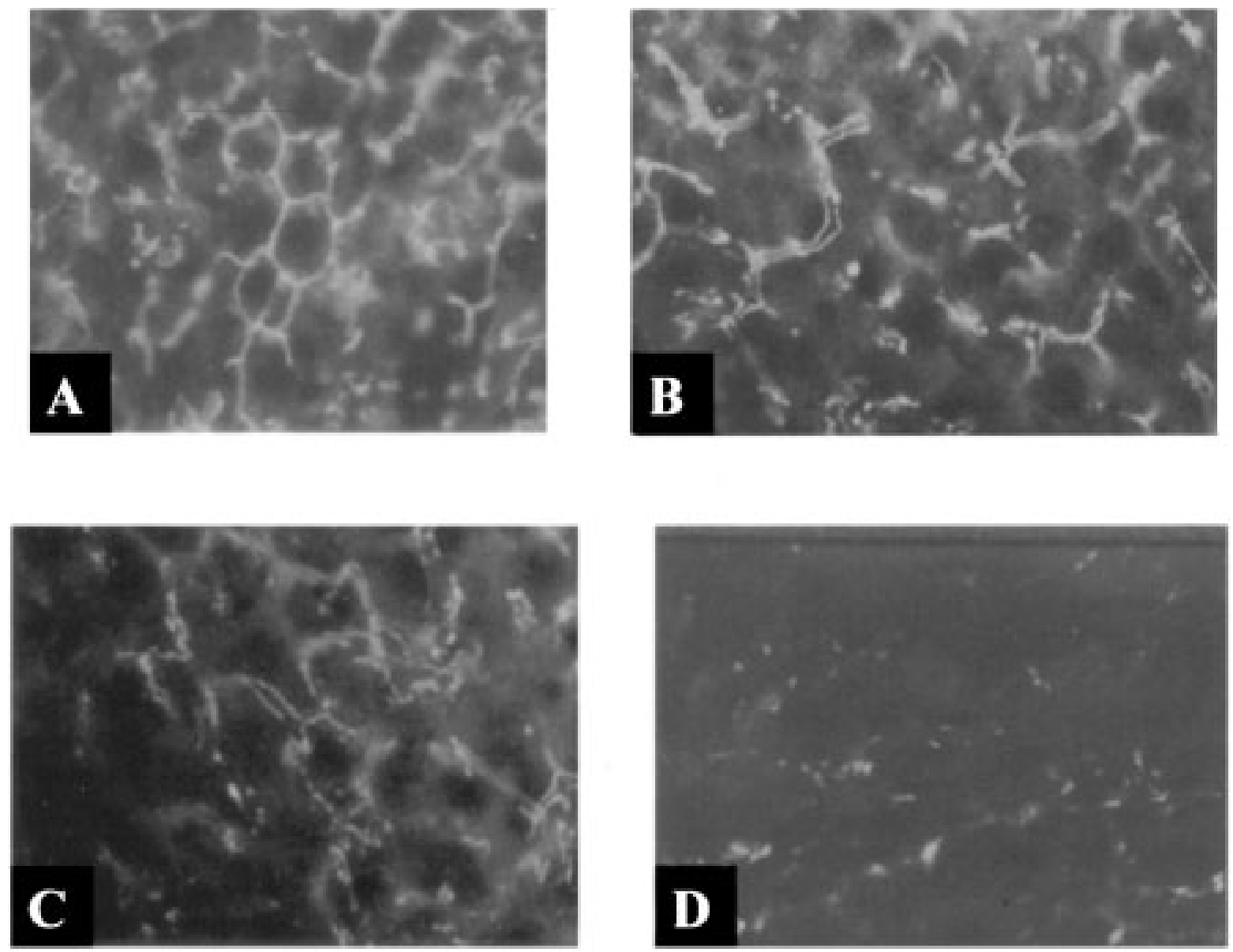

Fig. 12. Confocal laser scanning microscopic images. ZO-1 in sham-IL10WT mice (A), sham-IL10KO mice (B), DNBS-IL10WT mice (C) and in DNBS-IL10KO mice (D). Immunostaining for ZO-1 was localized bordering the bile canaliculi (A). In DNBS-IL10WT mice (C) the distribution of the protein was modified in comparison with sham-IL10WT mice. In contrast, the immunohistochemical localization of the ZO-1 in section of liver from DNBS-IL10KO mice was irregular and discontinuous (D).

\section{References}

1. Wewer V, Gluud C, Schlichting P, et al. (1991) Prevalence of hepatobiliary dysfunction in a regional group of patients with chronic inflammatory bowel disease. Scand. J. Gastroenterol. 26: 97-102.

2. Dordal E, Glagov S, Kirsner JB. (1967) Hepatic lesions in chronic inflammatory bowel disease. I. Clinical correlations with liver biopsy diagnoses in 103 patients. Gastroenterology 52: 239-253.

3. Schrumpf E, Fausa O, Elgjo K, Kolmannskog F. (1988) Hepatobiliary complications of inflammatory bowel disease. Semin. Liver Dis. 8: 201-209.

4. Sadlack B, Merz H, Schorle H, et al. (1993) Ulcerative colitislike disease in mice with a disrupted interleukin-2 gene. Cell. 75: 253-261.

5. Kuhn R, Lohler J, Rennick D, et al. (1993) Interleukin10-deficient mice develop chronic enterocolitis. Cell. 75: 263-274.

6. Claude P, Goodenough DA. (1973) Fracture faces of zonulae occludentes from tight and leaky epithelia. J. Cell Biol. 58: 390-400.

7. Schneeberger EE, Lynch RD. (1992) Structure, function, and regulation of cellular tight junctions. Am. J. Physiol. 262: L647-661.

8. Anderson JM, Van Itallie CM. (1995) Tight junctions and the molecular basis for regulation of paracellular permeability. Am. J. Physiol. 269: G467-475.
9. Furuse M, Hirase T, Itoh M, et al. (1993) Occludin: a novel integral membrane protein localizing at tight junctions. J. Cell Biol. 123: 1777-1788.

10. Furuse M, Fujita K, Hiiragi T, et al. (1998) Claudin-1 and -2: novel integral membrane proteins localizing at tight junctions with no sequence similarity to occludin. J. Cell Biol. 141: 1539-1550.

11. Morita K, Furuse M, Fujimoto K, Tsukita S. (1999) Claudin multigene family encoding four-transmembrane domain protein components of tight junction strands. Proc. Natl. Acad. Sci. USA. 96: 511-516.

12. Martin-Padura I, Lostaglio S, Schneemann M, et al. (1998) Junctional adhesion molecule, a novel member of the immunoglobulin superfamily that distributes at intercellular junctions and modulates monocyte transmigration. J. Cell Biol. 142: 117-127.

13. Stevenson BR, Siliciano JD, Mooseker MS, Goodenough DA. (1986) Identification of ZO-1: a high molecular weight polypeptide associated with tight junctions (zonula occludens) in a variety of epithelia. J. Cell Biol. 103: 755766.

14. Jesaitis LA, Goodenough DA. (1994) Molecular characterization and tissue distribution of $\mathrm{ZO}-2$, a tight junction protein homologous to ZO-1 and the Drosophila discs-large tumor suppressor protein. J. Cell Biol. 124: 949-961.

15. Haskins J, Gu L, Wittchen ES, Hibbard J, Stevenson BR. (1986) ZO-3, a novel member of the MAGUK protein family 
found at the tight junction, interacts with ZO-1 and occludin. J. Cell Biol. 141: 199-2087.

16. Zhong Y, Saitoh T, Minase T, (1993) Monoclonal antibody $7 \mathrm{H} 6$ react with a novel tight junction-associated protein distinct from ZO-1, cingulin and ZO-2. J. Cell Biol. 120: 477-483.

17. Citi S, Sabanay H, Jakes R, et al. (1988) Cingulin, a new peripheral component of tight junctions. Nature 333: 272-276.

18. Keon BH, Schafer S, Kuhn C, et al. (1996) Symplekin, a novel type of tight junction plaque protein. J. Cell Biol. 134: 10031018.

19. Fasano A, Baudry B, Pumplin DW, et al. (1991) Vibrio cholerae produces a second enterotoxin, which affects intestinal tight junctions. Proc. Natl. Acad. Sci. USA 88: 5242-5246.

20. Moore R, Pothoulakis C, LaMont JT, et al. (1990) C. difficile toxin A increases intestinal permeability and induces $\mathrm{Cl}$ secretion. Am. J. Physiol. 259: G165-172.

21. Nash S, Stafford J, Madara JL. (1988) The selective and superoxide-independent disruption of intestinal epithelial tight junctions during leukocyte transmigration. Lab Invest. 59: 531-537.

22. Mullin JM, Snock KV. (1990) Effect of tumor necrosis factor on epithelial tight junctions and transepithelial permeability. Cancer Res. 50: 2172-2176.

23. Madara JL, Stafford J. (1989) Interferon-gamma directly affects barrier function of cultured intestinal epithelial monolayers. J. Clin. Invest. 83: 724-727.

24. Lowe PJ, Miyai K, Steinbach JH, Hardison WG. (1988) Hormonal regulation of hepatocyte tight junctional permeability. Am. J. Physiol. 255: G454-461.

25. Kan KS, Monte MJ, Parslow RA, Coleman R. (1989) Oestradiol 17 beta-glucuronide increases tight-junctional permeability in rat liver. Biochem. J. 261: 297-300.

26. Elias E, Iqbal S, Knutton S, et al. (1983) Increased tight junction permeability: a possible mechanism of oestrogen cholestasis. Eur. J. Clin. Invest. 13: 383-390.

27. Moore KW, O'Garra A, de Waal Malefyt R, et al. (1993) Interleukin-10. Ann. Rev. Immunol. 11: 165-190.

28. Kuhn R, Lohler J, Rennick D, et al. (1993) Interleukin-10deficient mice develop chronic enterocolitis. Cell 75: 263-274.

29. Gudmundsson G, Bosch A, Davidson BL, et al. (1998) Interleukin-10 modulates the severity of hypersensitivity pneumonitis in mice. Am. J. Respir. Cell Mol. Biol. 19: 812-818.

30. Lora L, Mazzon E, Martines D, et al. (1997) Hepatocyte tightjunctional permeability is increased in rat experimental colitis. Gastroenterology 113: 1347-1354.

31. Morris GP, Beck PL, Herridge MS, et al. (1989) Hapten-induced model of chronic inflammation and ulceration in the rat colon. Gastroenterology 96: 795-803.

32. Yamada Y, Marshall S, Specian RD, Grisham MB. (1992) A comparative analysis of two models of colitis in rats. Gastroenterology 102: 1524-1534.

33. Lowe PJ, Kan KS, Barnwell SG, et al. (1985) Transcytosis and paracellular movements of horseradish peroxidase across liver parenchymal tissue from blood to bile. Effects of alpha-naphthylisothiocyanate and colchicine. Biochem. J. 229: 529-537.

34. Sturiale S, Barbara G, Qiu B, et al. (1999) Neutral endopeptidase (EC 3.4.24.11) terminates colitis by degrading substance P. Proc. Natl. Acad. Sci. USA 96: 11653-11658.

35. Hems R, Ross BD, Berry MN, Krebs HA. (1966) Gluconeogenesis in the perfused rat liver. Biochem. J. 101: 284-292.

36. Gores GJ, Kost LJ, LaRusso NF. (1986) The isolated perfused rat liver: conceptual and practical considerations. Hepatology 6: 511-517.

37. Zingarelli B, Szabo C, Salzman AL. (1999) Blockade of Poly(ADP-ribose) synthetase inhibits neutrophil recruitment, oxidant generation, and mucosal injury in murine colitis. Gastroenterology 16: 335-345.

38. Zingarelli B, Szabo C, Salzman AL. (1999) Reduced oxidative and nitrosative damage in murine experimental colitis in the absence of inducible nitric oxide synthase. Gut 45: 199-209.

39. Hayakawa T, Ng OC, Ma A, et al. (1990) Taurocholate stimulates transcytotic vesicular pathways labeled by horseradish peroxidase in the isolated perfused rat liver. Gastroenterology 99: 216-228.

40. Kan KS, Monte MJ, Parslow RA, Coleman R. (1989) Oestradiol 17 beta-glucuronide increases tight-junctional permeability in rat liver. Biochem. J. 261: 297-300.

41. Lora L, Mazzon E, Billington D, et al. (1997) Effects of cyclosporin A on paracellular and transcellular transport of horseradish peroxidase in perfused rat livers. Dig. Dis. Sci. 42: 514-521.

42. Kawaguchi T, Sakisaka S, Mitsuyama K, et al. (2000) Cholestasis with altered structure and funcion of hepatocyte tight junction and decreased expression of canalicular multispecific organic anion transporter in a rat model of colitis. Hepatology 31: 1285-1295.

43. Fanning AS, Jameson BJ, Jesaitis LA, Anderson JM. (1998) The tight junction protein $\mathrm{ZO}-1$ establishes a link between the transmembrane protein occludin and the actin cytoskeleton. J. Biol. Chem. 273: 29745-29753.

44. Furuse M, Itoh M, Hirase T, et al. (1994) Direct association of occludin with ZO-1 and its possible involvement in the localization of occludin at tight junctions. J. Cell Biol. 127: 1617-1626.

45. Green RM, Beier D, Gollan JL. (1996) Regulation of hepatocyte bile salt transporters by endotoxin and inflammatory cytokines in rodents. Gastroenterology 111: 193-198.

46. Kubitz R, Wettstein M, Warskulat U, Haussinger D. (1999) Regulation of the multidrug resistance protein 2 in the rat liver by lipopolysaccharide and dexametasone. Gastroenterology 116: 401-410.

47. Spitzer JA, Deaciuc IV. (1987) IP3-dependent $\mathrm{Ca}^{2+}$ release in permeabilized hepatocytes of endotoxemic and septic rats. Am. J. Physiol. 253: E130-134.

48. Kimura H, Sawada N, Tobioka H, et al. (1997) Bacterial lipopolysaccharide reduced intestinal barrier function and altered localization of $7 \mathrm{H} 6$ antigen in IEC- 6 rat intestinal crypt cells. J. Cell Physiol. 171: 284-290.

49. Bolder U, Ton Nu HT, Schteingart CD, et al. (1997) Hepatocyte transport of bile acids and organic anions in endotoxemic rats: impaired uptake and secretion. Gastroenterology 112: 214-225.

50. Zech JC, Pouvreau I, Cotinet A. (1998) Effect of cytokines and nitric oxide on tight junctions in cultured rat retinal pigment epithelium. Invest. Ophtalmol. Vis. Sci. 39: 1600-1608.

51. Maruo N, Morita I, Shirao M, Murota S. (1992) IL-6 increases endothelial permeability in vitro. Endocrinology 131: 710-714.

52. Fiorentino DF, Bond MW, Mosmann TR. (1989) Two types of mouse $\mathrm{T}$ helper cell. IV. Th 2 clones secrete a factor that inhibits cytokine production by Thl clones. J. Exp. Med. 170: 2081

53. Hsu DH, de Malefyt RW, Fiorentino DF et al. (1990) Expression of interleukin-10 activity by Epstein-Barr virus protein BCRF1. Science 250: 830.

54. Moore KW, Vieira P, Fiorentino DF, et al. (1990) Homology of cytokine synthesis inhibitory factor (IL-10) to the EpsteinBarr viru gene BCRF1. Science 248: 1230.

55. Vieira $P$, de Waal-Malefyt $R$, Dang $M N$, et al. (1991) Isolation and expression of human cytokine synthesis inhibitory factor (CSIF/IL-10) cDNA clones: Homology to Epstein-Barr virus open reading frame BCRF1. Proc. Natl. Acad. Sci. USA 88: 1172.

56. De Waal-Malefyt R, Abrams J, Bennet B, et al. (1991) Interleukin-10 (IL-10) inhibits cytokine synthesis by human monocytes. J. Exp. Med. 174: 1209.

57. Bogdan C, Vodovotz Y, Nathan C. (1991) Macrophage deactivation by IL-10. J. Exp. Med. 174: 1549.

58. Fiorentino DF, Zlotnik A, Mosmann TR, et al. (1991) IL-10 inhibits cytokine production by activated macrophages. J. Immunol. 147: 3815.

59. Cassatella MA, Meda L, Bonora S, et al. (1993) Interleukin-10 inhibits the release of proinflammatory cytokines from human polymorphonuclear leukocytes. Evidence for an autocrine role of tumour necrosis factor and IL-lbeta in mediating the production of IL-8 triggered by lipopolysaccharide. J. Exp. Med. 178: 2207. 
60. Kasama T, Strieter RM, Lukacs NW, et al. (1994) Regulation of neutrophil-derived chemokine expression by IL- 10 . J. Immunol. 152: 3559.

61. Madsen KL. (2001) Inflammatory bowel disease: lessons from the IL-10 gene-deficient mouse. Clin. Invest. Med. 245: 250-257.

62. Oshima T, Laroux FS, Coe LL, et al. (2001) Interferongamma and interleukin-10 reciprocally regulate endothelial junction integrity and barrier function. Microvasc. Res. 61: 130-143.
63. Barbara G, Xing Z, Hogaboam CM, et al. (2000) Interleukin-10 gene transfer prevents experimental colitis in rats. Gut 46: 344-349.

64. Asseman C, Mauze S, Leach MW, et al. (1999) An essential role for interleukin-10 in the function of regulatory $\mathrm{T}$ cells that inhibit intestinal inflammation. J. Exp. Med. 190: 9951004.

65. Goldblum SE, Wu KM, Jay M. (1985) Lung myeloperoxidase as a measure of pulmonary leukostasis in rabbits. J. Appl. Physiol. 59: 1978. 